Article

\title{
Delay Factors in Reconstruction Projects: A Case Study of Mataf Expansion Project
}

\author{
Basem Al Khatib, Yap Soon Poh® and Ahmed El-Shafie * \\ Department of Civil Engineering, Faculty of Engineering, University Malaya, 50603 Kuala Lumpur, Malaysia; \\ eng.basemkhatib@gmail.com (B.A.K.); spyap@um.edu.my (Y.S.P.) \\ * Correspondence: elshafie@um.edu.my; Tel.: 006-03-7967-7651
}

Received: 21 November 2018; Accepted: 12 December 2018; Published: 14 December 2018

check for updates

\begin{abstract}
Delays in construction projects are a common phenomenon throughout the industry. This problem has many negative impacts on the time, cost, and sustainability of the projects. Many studies were conducted to identify the main causes of this delay in new construction projects in different regions but very few studies have focused on finding an explanation for the causes of delay in major reconstruction projects that have great religious and cultural sustainability. This paper examines the factors that contributed to work delays in one of the most major reconstruction projects that took place recently in the Middle East, which is namely the Mataf Expansion Project in the city of Mecca, Saudi Arabia. Fourteen interviews were conducted with project managers, construction managers, and senior site engineers to identify the factors that they encountered and led to the delay in the reconstruction activities of this project. Some of the findings were consistent and similar to most other causes of delay that are associated with new construction projects. However, interestingly, this research has discovered the existence of other unavoidable factors that caused a delay and should be considered for any similar reconstruction projects. The results showed that these factors could be divided into two groups: the first one is related to the demolition phase (five factors) and the second group is related to construction works (nine factors). In addition, it has been observed that the building material during the reconstruction is considered one of the major delaying factors. Finally, these 14 delay factors should be carefully considered to assure the sustainability of the main object's function during the reconstruction activities.
\end{abstract}

Keywords: reconstruction projects; delay factors; construction project; sustainable constructions; Mecca

\section{Introduction}

Delays in the construction industry are very common and important problems that should be further investigated. This problem affects not only the construction sector but also the growth of the economy and the sustainable development of nations [1,2]. Chan [3] mentioned that the time overrun (delay) is the difference between the actual period for project completion and the estimated period for project completion. Another way to describe a project delay is by defining it as the time overrun against the contract period [4]. As a result of delays within the original project schedule, the total cost of the project will be increased for both the client and contractor, which might affect project sustainability $[5,6]$. In addition, the time required to complete the project will be readjusted to be longer and hence, will definitely lead to negative impacts on both the project duration and relationship between project parties. The factors causing delay and their impacts on the construction projects differ greatly between countries. These differences are derived from the work environment, technology, and other constraints $[7,8]$. Many studies have been conducted to identify the delay factors related to new construction projects, but few studies have focused on the factors related to reconstruction projects. 
In general, there are many aims for reconstruction building projects, such as increasing the building capacity, updating the mechanical, electrical, and plumbing (MEP) utilities and systems, achieving commercial aims, and sustainability purposes, particularly for large projects. The previous goals for reconstruction projects will not be achieved on time if the reconstruction work is delayed. As a result of the delay, a considerable number of problems may arise between the main parties of the project (contractor, owner, and consultant) and might turn out to be an essential challenge that needs to be solved.

Therefore, the aim of this study is to identify and discuss the most relevant delay factors in reconstruction projects. This objective is chosen in order to avoid or reduce the potential problems and their effects in future reconstruction projects. Furthermore, this will provide guidance on how to better manage delays and to mitigate their impacts, which could improve the sustainability of projects.

\section{Delay Factors for Construction Projects}

According to most research during the last three decades, the important delay factors related to construction projects were collected, and after reviewing these factors, it was clear that there is overlap in the delay factors existing between previous studies. As a result, the number of delay factors was 45 factors, which are detailed in Table 1. As depicted in Table 1, which shows the summary of the delay factors highlighted in the previous studies, column 1 shows the factor number, while column 2 shows a delay factor description, whereas column 3 shows the references to each delay factor. The last column in Table 1, which is titled Delay Factor Index, shows the number of the previous studies that highlighted common delay factors.

In fact, the 45 factors have been arranged in Table 1 according to the delay factor index from the most frequent factor to the least frequent one, as shown in the last column in the table. This index displays the similarity in the delay factors although the studies were conducted in different countries.

Although the projects are different in purpose and are even implemented in different countries, the delay factors have almost a similar influence on the project's schedule.

Most of the previous studies mentioned in Table 1 indicated that the financial problems and difficulties of the contractor and owner are the most critical factor according to the delay factor index, as it is the most frequent factor that occurred in 34 out of the 45 studies. Actually, if the budget is not observed, this can lead to many financial problems [9]. For example, construction work in the project might be stopped if the salaries for direct and indirect manpower are not paid on time, the required materials are unavailable, and many issues occur with the suppliers and subcontractors.

On the other hand, the least frequent critical factors in Table 1 are incomplete documents, delay in performing inspection and testing, excessive bureaucracy in project-owner organization, frequent interruptions from public (local people, pressure groups, etc.), lack of clarity in project scope, land expropriation, segmentation of the West Bank, sources of information, and works in conflict with existing utilities, which have been mentioned only in one study with a delay factor index equal to one.

Furthermore, the second most frequent factor in Table 1 is shortages of skilled workers, with a delay factor index equal to 18. Indeed, the availability of skilled manpower means speed in the execution of works and avoiding the reworks and any defective works. Thus, the project could be delayed due to the shortage of skilled workers.

The third most frequent factor in Table 1 is improper planning, with a delay factor index equal to 15. In fact, a good plan reflects a good survey of all the project aspects, such as project duration, safety, quality, and construction methods. Improper planning can result in problems during the project execution phase.

Moreover, the fourth most frequent factor is change orders, with a delay factor index equal to 14. The fifth most frequent factors are delay and shortages of materials, and poor site management and supervision, with a delay factor index equal to 14, while the sixth most frequent factor is poor communication and coordination between construction parties with a delay factor index equal to 12 . The seventh most frequent factor is design changes and modification, with a delay factor index equal to 
ten, while the eighth most frequent factor is lack of qualified and experienced personnel, with a delay factor index equal to nine. However, the ninth most frequent factor is poor labor productivity and subcontractors' incompetency, with a delay factor index equal to seven. The 10th most frequent factors are bid award for lowest price, lack of contractor experience, poor contract management, slow decision making from owner, and unrealistic project duration, with a delay factor index equal to six. Moreover, the 11th most frequent factors are difficulties in obtaining work permits, poor contractor management, and price escalation, with a delay factor index equal to five. The 12th most frequent factors are design errors, construction mistakes and defective works, poor qualification of consultants, shortage of equipment, the type of contract, unforeseen ground conditions, weather conditions, and political insecurity and instability, with a delay factor index equal to four. The 13th most frequent factors are construction methods, discrepancies between drawings and specifications, escalation of material prices, and poor site conditions, with a delay factor index equal to three. The 14th most frequent factors are delay in site delivery, inaccurate estimating, inadequate tools and equipment, and preparation and approval of shop drawings, with a delay factor index equal to two.

Table 1. Summarized factors causing delay through a group of previous studies.

\begin{tabular}{|c|c|c|c|}
\hline No. & Delay Factor & Reference & Delay Factor Index \\
\hline 1 & $\begin{array}{l}\text { Financial problems and difficulties of } \\
\text { contractor \& owner }\end{array}$ & [10-43] & 34 \\
\hline 2 & Shortages of skilled workers & {$[10,11,13,16,18,19,25,29,31,33,37,39,43-48]$} & 18 \\
\hline 3 & Improper planning and scheduling & {$[10,15,16,18,19,26,27,30,31,33,34,37,45,47,49]$} & 15 \\
\hline 4 & Change orders & {$[11,12,15,16,18-20,23,30,35,37,43,45,50]$} & 14 \\
\hline 5 & Delay \& shortages of materials & {$[11,18,19,23,26,29,31,33,34,36,40,44,48]$} & 13 \\
\hline 6 & Poor site management and supervision & {$[12-14,17-19,24,27,29,31,33,49,50]$} & 13 \\
\hline 7 & $\begin{array}{l}\text { Poor communication and coordination } \\
\text { between construction parties }\end{array}$ & {$[10,12,15,17,18,21,27,29,31,32,35,50]$} & 12 \\
\hline 8 & Design changes \& modification & {$[14,18,19,22,25,26,28,29,39,47]$} & 10 \\
\hline 9 & $\begin{array}{l}\text { Lack of qualified and } \\
\text { experienced personnel }\end{array}$ & {$[16,20,24,36,43,44,46,51]$} & 8 \\
\hline 10 & Poor labor productivity & {$[10,15,17,19,33,39,47]$} & 7 \\
\hline 11 & Subcontractors' incompetency & {$[13,18,26,27,31,34,39]$} & 7 \\
\hline 12 & Bid award for lowest price & {$[17,19,21,23,35,37]$} & 6 \\
\hline 13 & Lack of contractor experience & {$[12,15,16,18,31,35]$} & 6 \\
\hline 14 & Poor contract management. & {$[10,12,27-29,40]$} & 6 \\
\hline 15 & Slow decision making from owner & {$[11,16,18,33,39,50]$} & 6 \\
\hline 16 & Unrealistic project duration & {$[14,15,23,35,37,52]$} & 6 \\
\hline 17 & Difficulties in obtaining work permits & {$[14,23,29,33,37]$} & 5 \\
\hline 18 & Poor contractor management & {$[29,36,38,45,49]$} & 5 \\
\hline 19 & Price escalation & {$[14,29,34,40,42]$} & 5 \\
\hline 20 & Design errors & {$[11,34,39,52]$} & 4 \\
\hline 21 & Construction mistakes and defective works & {$[12,15,17,31]$} & 4 \\
\hline 22 & Design delays & {$[10,18,43,45]$} & 4 \\
\hline 23 & Poor qualification of consultants & {$[11,16,19,35]$} & 4 \\
\hline 24 & Shortage of equipment & {$[19,21,31,44]$} & 4 \\
\hline 25 & The type of contract & {$[19,38,41,49]$} & 4 \\
\hline 26 & Unforeseen ground conditions & {$[18,35,37,50]$} & 4 \\
\hline 27 & Weather conditions & {$[12,16,35,41]$} & 4 \\
\hline 28 & Political insecurity and instability & {$[14,20,21,24]$} & 4 \\
\hline
\end{tabular}


Table 1. Cont.

\begin{tabular}{|c|c|c|c|}
\hline No. & Delay Factor & Reference & Delay Factor Index \\
\hline 29 & Construction methods & {$[27,29,41]$} & 3 \\
\hline 30 & $\begin{array}{l}\text { Discrepancies between drawings } \\
\text { and specifications }\end{array}$ & {$[11,14,16]$} & 3 \\
\hline 31 & Escalation of material prices & {$[36,42,44]$} & 3 \\
\hline 32 & Poor site conditions & {$[12,29,52]$} & 3 \\
\hline 33 & Delay in site delivery & {$[18,52]$} & 2 \\
\hline 34 & Inaccurate estimating & {$[25,40]$} & 2 \\
\hline 35 & Inadequate tools and equipment & {$[26,34]$} & 2 \\
\hline 36 & Preparation and approval of shop drawings & {$[33,39]$} & 2 \\
\hline 37 & Incomplete documents & [12] & 1 \\
\hline 38 & Delay in performing inspection and testing & [18] & 1 \\
\hline 39 & $\begin{array}{l}\text { Excessive bureaucracy in } \\
\text { project-owner organization }\end{array}$ & [39] & 1 \\
\hline 40 & $\begin{array}{l}\text { Frequent interruptions from public } \\
\text { (local people, pressure groups, etc.) }\end{array}$ & [52] & 1 \\
\hline 41 & Lack of clarity in project scope & [49] & 1 \\
\hline 42 & Land expropriation & [23] & 1 \\
\hline 43 & Segmentation of the West Bank & [21] & 1 \\
\hline 44 & Sources of information & [41] & 1 \\
\hline 45 & Works in conflict with existing utilities & [35] & 1 \\
\hline
\end{tabular}

However, a few studies were developed in order to determine the delay factors in reconstruction projects. Krizek et al. [53] in the United States mentioned that many reconstruction projects were more difficult and more complicated to execute than new projects due to the constraints and the conditions of the existing buildings. According to their study, the factors causing delay and other problems were reflected in some lessons learned, including: more need for active management at all project levels and close coordination between all contract parties in order to render the required decisions on time, clear contract documents without any conflicts, providing a strong basis to solve all issues and changes during construction period, and special problems, such as changing the designer and contractor during the project phases.

Pavlovskis et al. [54] investigated the problems in reconstruction projects in Lithuania. The critical factors causing delay, which cause an extension in project duration and increase project expenses, were: unqualified project staff, poor documentation, and long procedure period for purchasing required materials.

\section{Research Methodology}

The summarized factors causing delay that were determined through previous studies and are shown in Table 1 are reflected in Figure 1, which demonstrates the delay factors with the delay factor index value. Figure 1 formed the basis of the dialogue during the interviews that were held with the experts working in the Mataf Expansion Project in Mecca in Saudi Arabia, which is an example and case study of reconstruction projects of great importance. This project is one of the most major reconstruction projects undertaken recently in the Middle East. It clarifies the difficulties and obstacles facing this type of reconstruction project, which combines demolition and construction works at the same time while the object is under operation. In addition, it has been considered to highlight a few delay factors that have not been mentioned in previous studies in similar types of projects. Moreover, this project is a very crowded place and receives millions of visitors each year and should be at least partially opened during the whole year. 


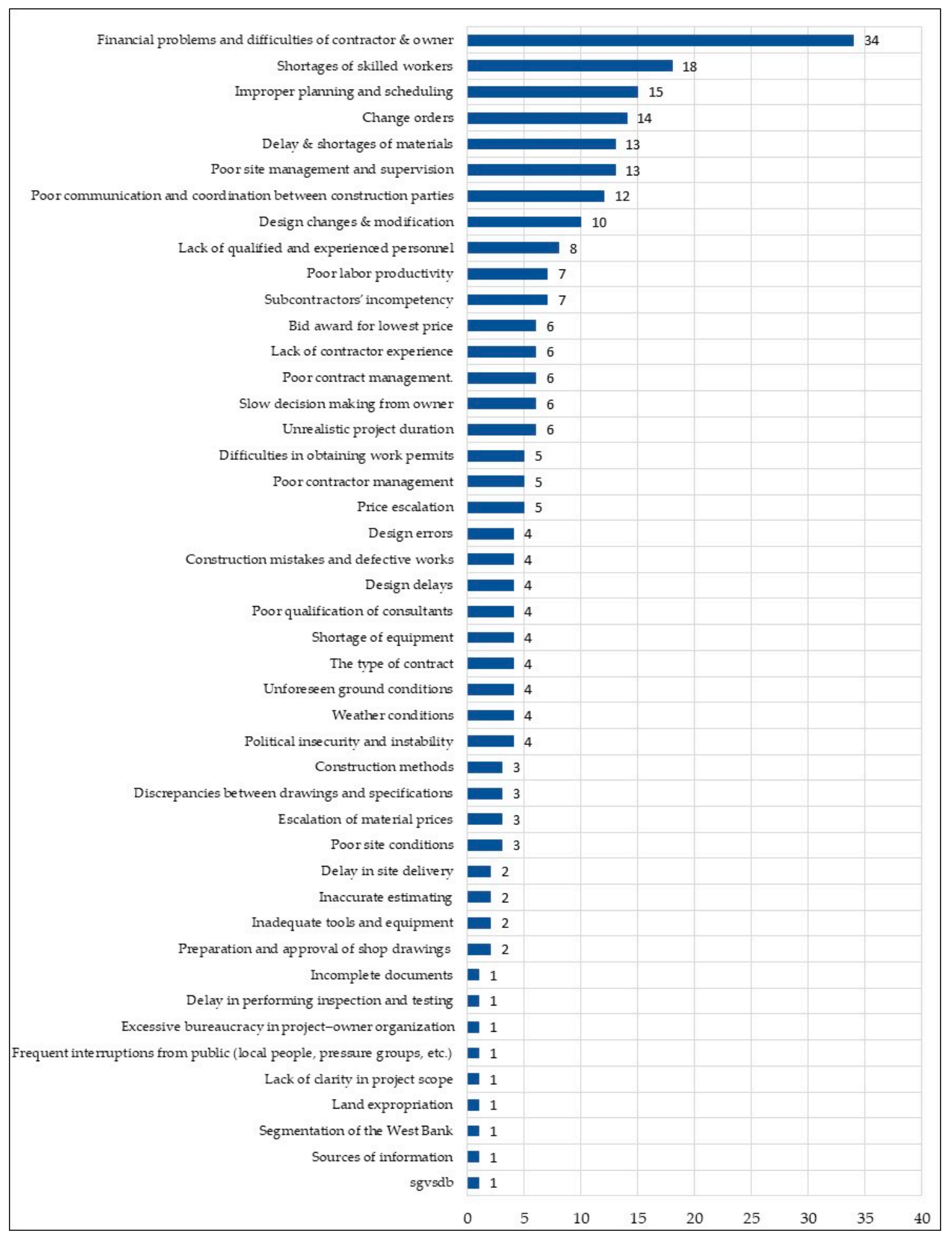

Figure 1. Delay factors index.

Fourteen interviews were held with the experts working in the Mataf Expansion Project for different levels of seniority. The seniority level included two project managers, two construction managers, two planning engineers, six site engineers, and two technical engineers. In addition, it has been decided to consider the years of experience for all the experts to be at least eight years' experience in the construction industry. The main objective of these interview sessions was to identify the delay factors in the reconstruction projects regardless of the ranking of these factors. Furthermore, the sample size " 14 interviewees" in such a qualitative research method, which depends on the interviews in 
order to collect the required data and information, can be identified through saturation. That means that any additional interviews that do not produce new data or information could be omitted from the analysis [55]. Actually, this subject was carried out by 2 additional interview sessions with 2 different senior site engineers in order to confirm the outcomes of the 14 interview sessions.

During the interview sessions, the delay factors that have been acquired from the previous studies were investigated by briefing the interviewees the details presented in Figure 1. Subsequently, the delay factors in the reconstruction project "as in the case study" were discussed and recorded.

As it has been shown in Figure 1, this arrangement plays an important and positive role in breaking the barrier that is usually common in the interview sessions. In fact, there are always limits on the researchers when asking a set of questions and recording the answers from the experts being interviewed due to the time constrains of the experts' responses. In a few cases, the expert might respond quickly to the researcher's questions without paying the required attention to the question, especially when the expert might be unable to easily catch the whole picture of the purpose of the research's aim during the interview or to perceive the desired benefits from this research. Therefore, it has been decided to incorporate all the tables and figures to keep visualizing all the required data and information to the experts being interviewed to ensure that the data and information are available to provide the proper feedback. The interview questions and format were designed in a proper way in order to cover the previous study factors and to identify the reconstruction delay factors. The main questions were:

First question: "Do you think, as an expert in this project, this factor causes delay in reconstruction projects?" Second question: "Are there any further factors that cause delays that you might think are important to add?"

The research methodology can be summarized by the below Figure 2.

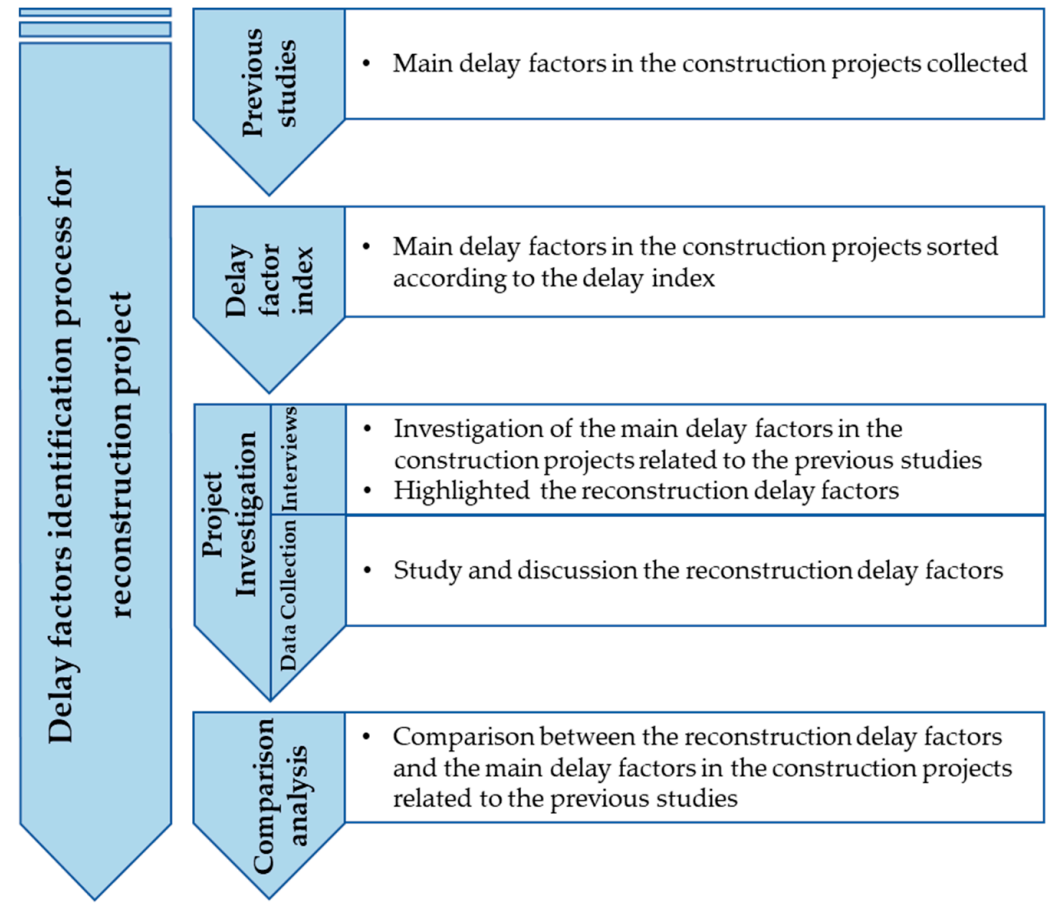

Figure 2. Research methodology framework project.

\section{Case Study and Data Collection}

During the interviews, the experts pointed out that the work in the project was divided into three major phases because of the importance and sanctity of the project, which prevents its closing as a whole, as in Figure 3. 


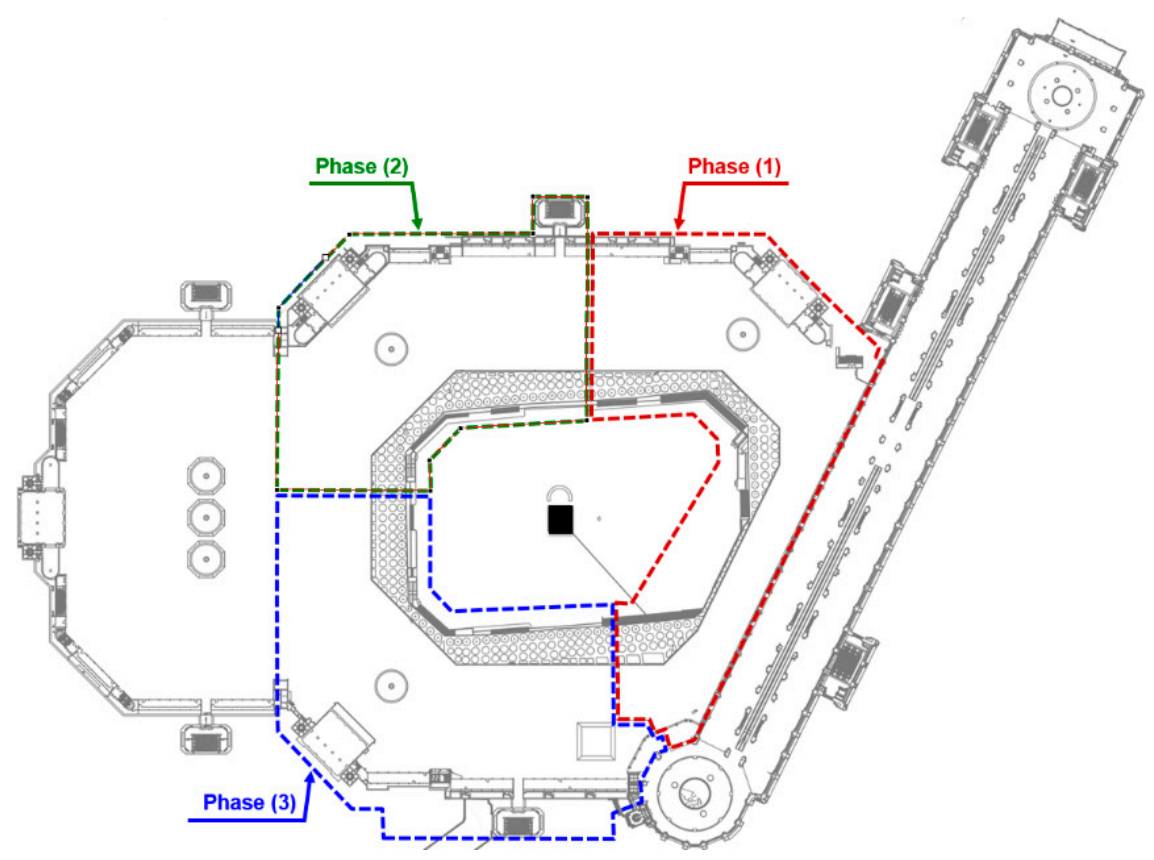

Figure 3. Major reconstruction phases of Mataf Expansion Project.

The division of the project into three phases guarantees the continuity of the project operation during the execution phase but it imposed other restrictions on the project to ensure the safety of visitors and reduce the noise generated by the work.

Each phase in the project is divided as the following: 4.1. Demolition and dismantling phase; 4.2. Construction phase.

\subsection{Demolition and Dismantling Phase}

This phase includes two main types of work, as in Figure 4: demolition of nonarchaeological part, number 1 in Figure 4.; dismantling of archaeological part, number 2 in Figure 4.

In order to avoid possible delays in the demolition phase, a similar demolition prototype was built to study the methods, tools, and suitable equipment for demolition works, which would be implemented at the site during the execution of demolition works. In fact, the experts mentioned during the interviews five factors which led to a delay in the demolition phase.

Actually, the first factor that was mentioned was the rerouting works for all electrical and mechanical utilities in the area to be demolished. For safety purposes, the demolition area in the first phase of the project was surrounded by a temporary fence and isolated from the other phases of the project. However, the demolition works did not start in some areas in phase one and did not finish in other areas until the completion of rerouting works for electrical and mechanical services. Moreover, alternative routes were provided to ensure the continuity of these services in the remaining phases of the project.

In fact, there was a need to delay the demolition of a few parts within the demolition area because it was the only access for visitors from outside the demolition area until the establishment of new alternative safe access. Although the work in the project was divided into phases, the working team was unable to completely separate the first phase from the remaining phases of the project because of the need for safe paths in the demolition area to allow visitors to move between the project areas. Accordingly, the demolition works were delayed in some areas of the project and this is illustrated in Figures 5-7. The safe paths are considered an indispensable, inevitable, logistical necessity and it is a major reason for the demolition delay as the experts mentioned during the interviews. Indeed, as shown in Figure 5, the upper floor was demolished within the safe path area using the cutting method of concrete slabs and columns and shifting them by using the tower cranes outside the object 
area. However, the safe path, which was located in the lower floor area, prevented completion of the demolition work in the lower floor as it was considered as the main route for the visitors to move between the parts of the object. Recall that the object should be in operation during the demolition and construction process and the visitors should be able to move safely from inside to outside and vice versa in the project area as shown in Figure 5.

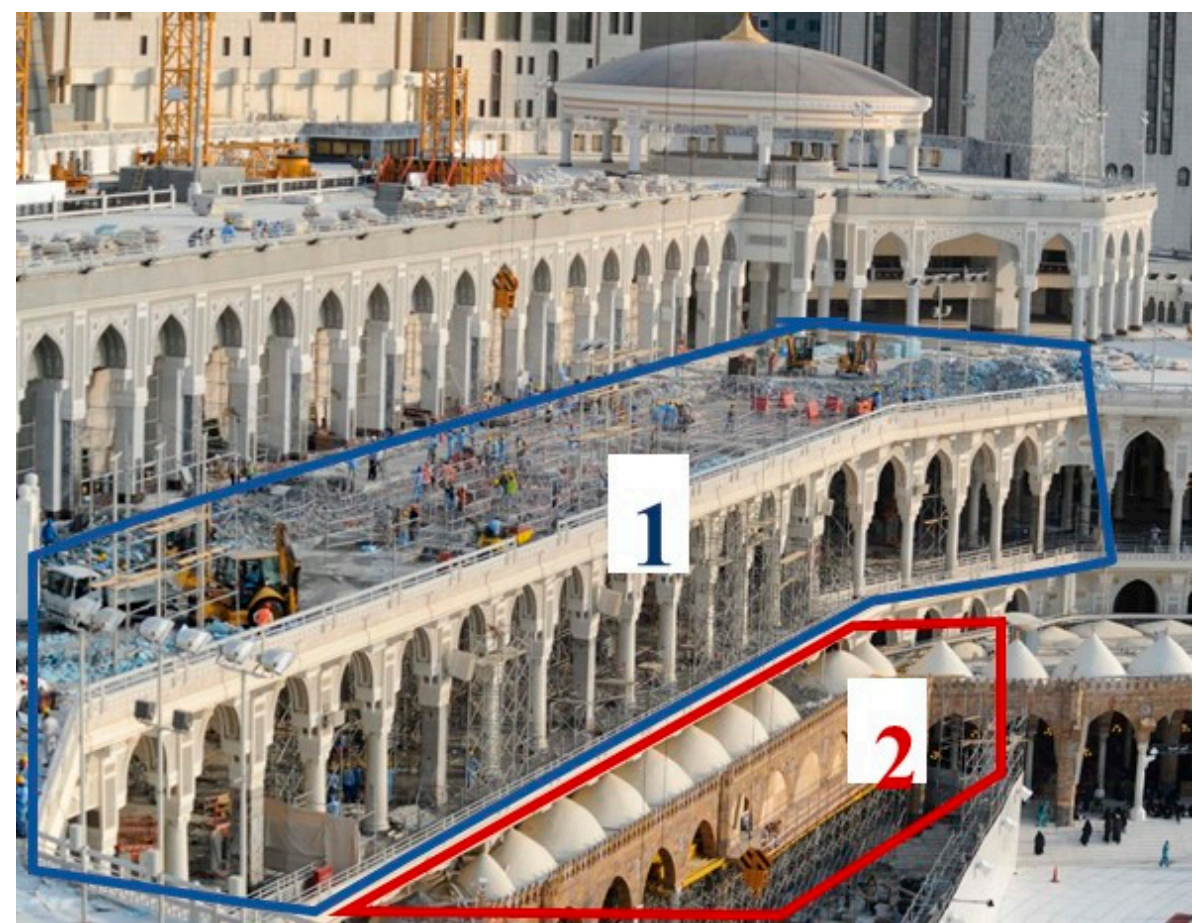

Figure 4. Demolition and dismantling phase; number 1 area bounded by blue color is a nonarchaeological part, while number 2 area bounded by red color is an archaeological part.

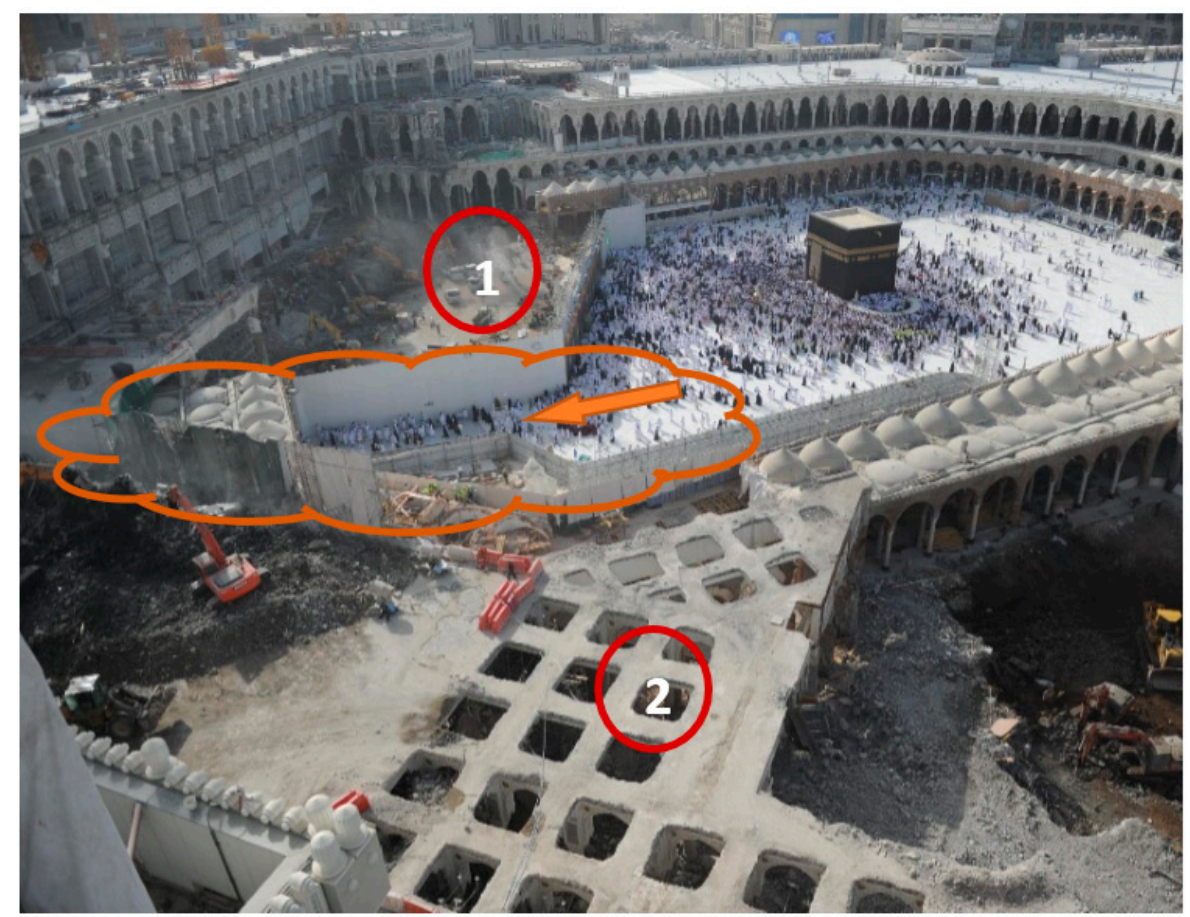

Figure 5. The clouded area in early stage of the project, showing the safe path for people which divided the phase one demolition area into two parts $(1 \& 2)$. 


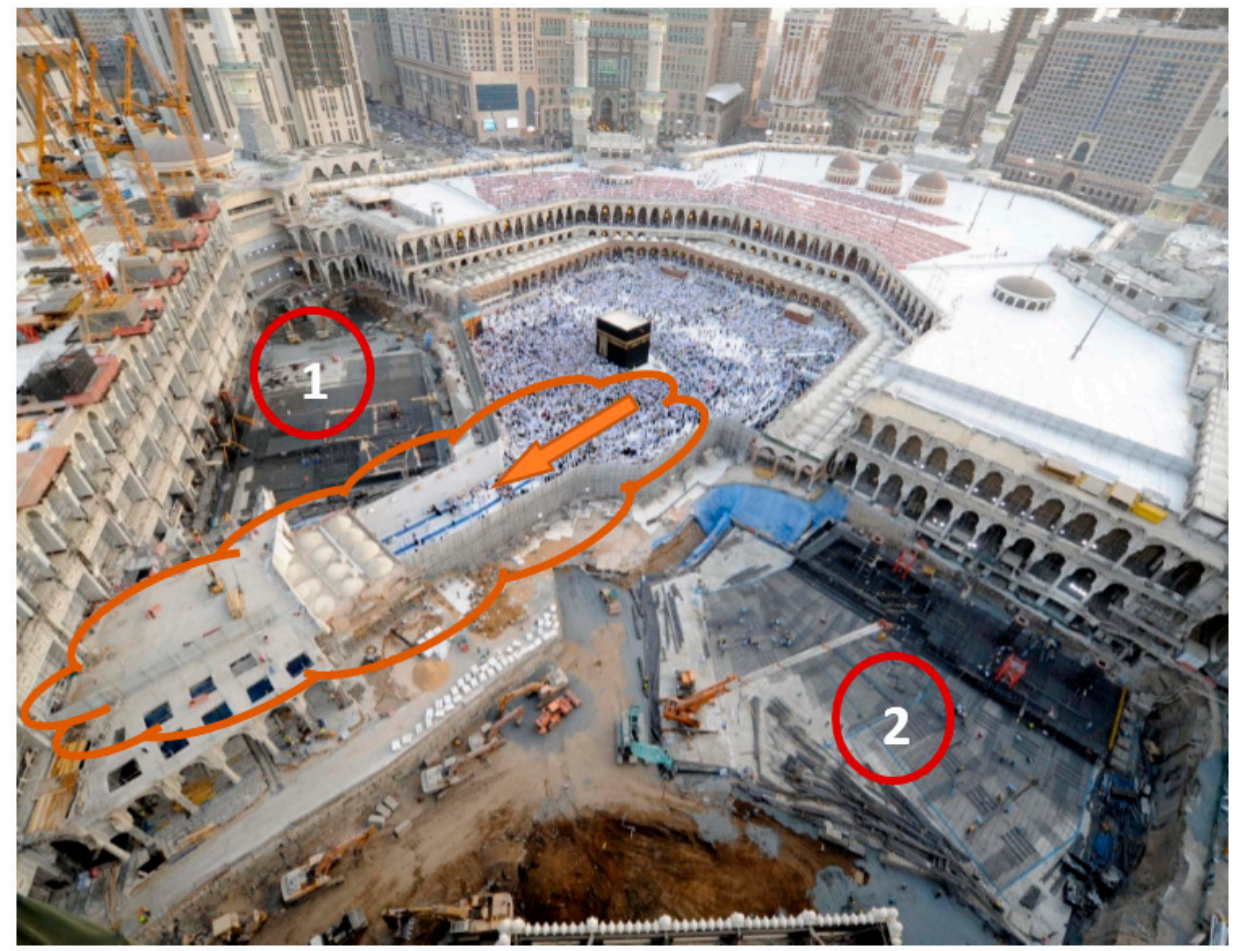

Figure 6. The clouded area shows the safe path for people, which could not be demolished, while the construction works started in parts (1\&2).

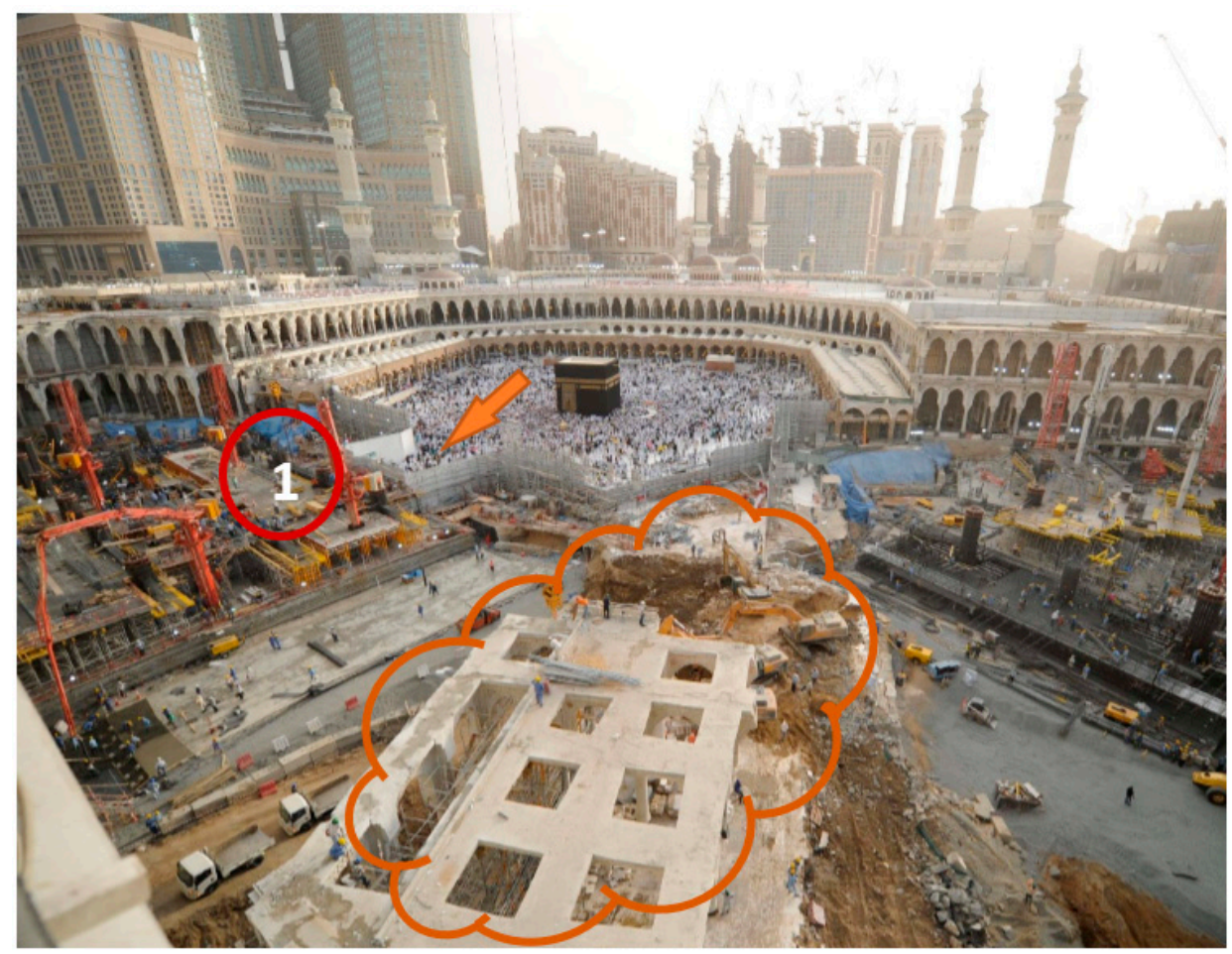

Figure 7. The clouded area shows the last stage of demolition works started in the previous safe path after preparing a new safe path for people in the new construction area part (1) as highlighted by the arrow. 
Another factor that was mentioned was the site conditions and constraints, which imposed a number of limitations on the size of the tools and equipment operating in the project, because of the size of the entrances and exits and accesses of the project and the difficulty in delivering large-sized equipment to the work site.

Furthermore, there was the factor related to dismantling archaeological and antiquity elements. This factor has been experienced due to the overlap between the archaeological and nonarchaeological areas in the project. As shown in Figures 4-6, the archaeological domes elements are located under the nonarchaeological concrete slab. As a result of this overlap, the demolition phase in some areas was delayed until the dismantling of domes, columns, and other archaeological elements due to the special building materials used in constructing these domes. Such building materials are very sensitive and require special protection works, packing, numbering, and reinforcement before starting the dismantling work. In addition, all the protection procedures were carried out carefully in order to keep the building materials of the domes, arches, columns, and other archaeological elements in proper condition due to the limitations of having similar building materials nowadays. In fact, the protection procedures formed the basic foundations in order to assure the sustainability of the archaeological elements as in Figures 8 and 9, especially after execution of the required testing and treatments.

Furthermore, there was a back-propping works factor. The demolition work in the project did not start until the completion of the required back-propping works in all the floors. However, the continuity of the operation work in the project during the demolitions and the presence of safe accesses in the demolition area, which allowed the visitors to move between the project phases, required the implementation of extra propping works, which led to the delay in the demolition work in some of the project areas.

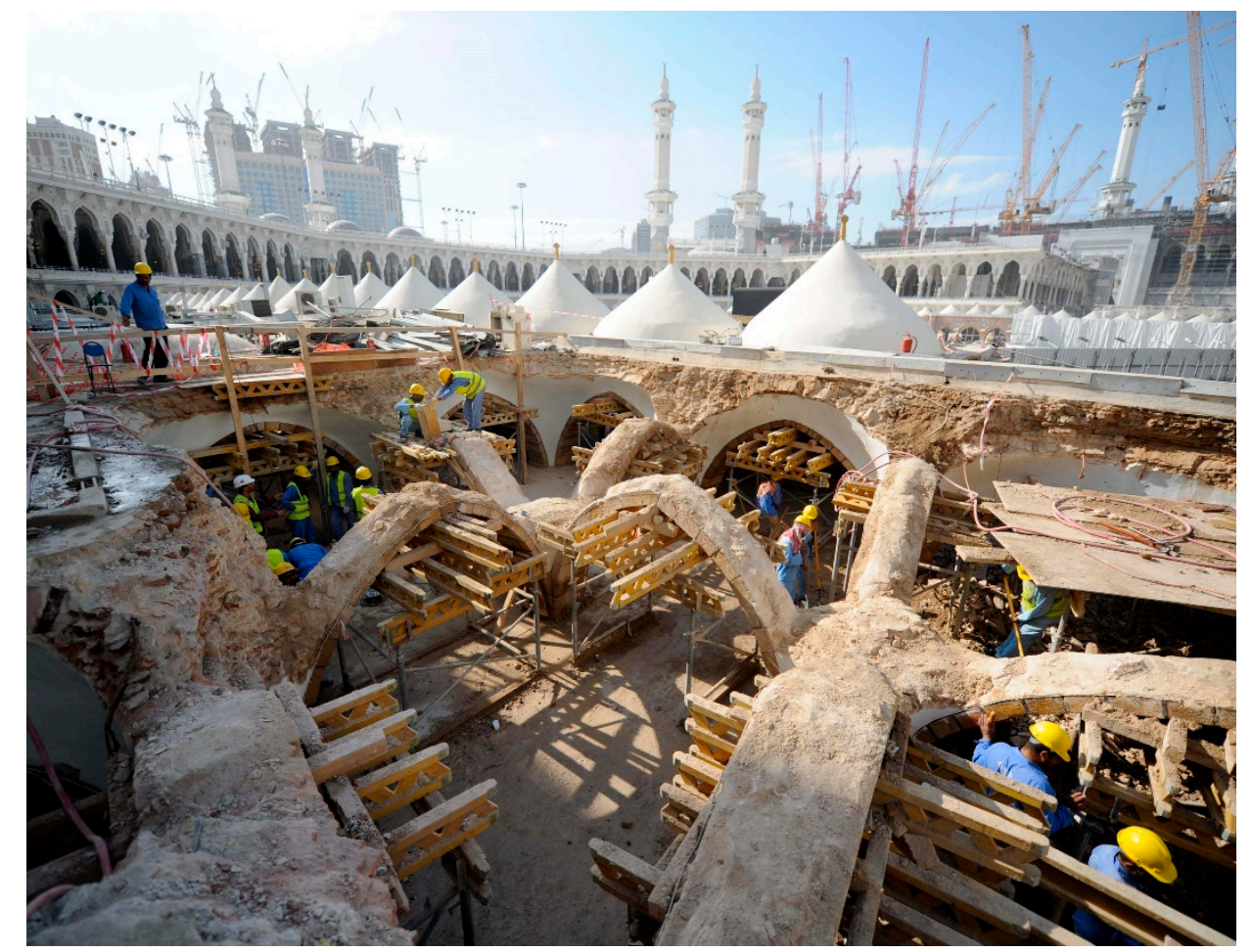

Figure 8. Dismantling and protection procedures for the archaeological arches for more sustainability. 


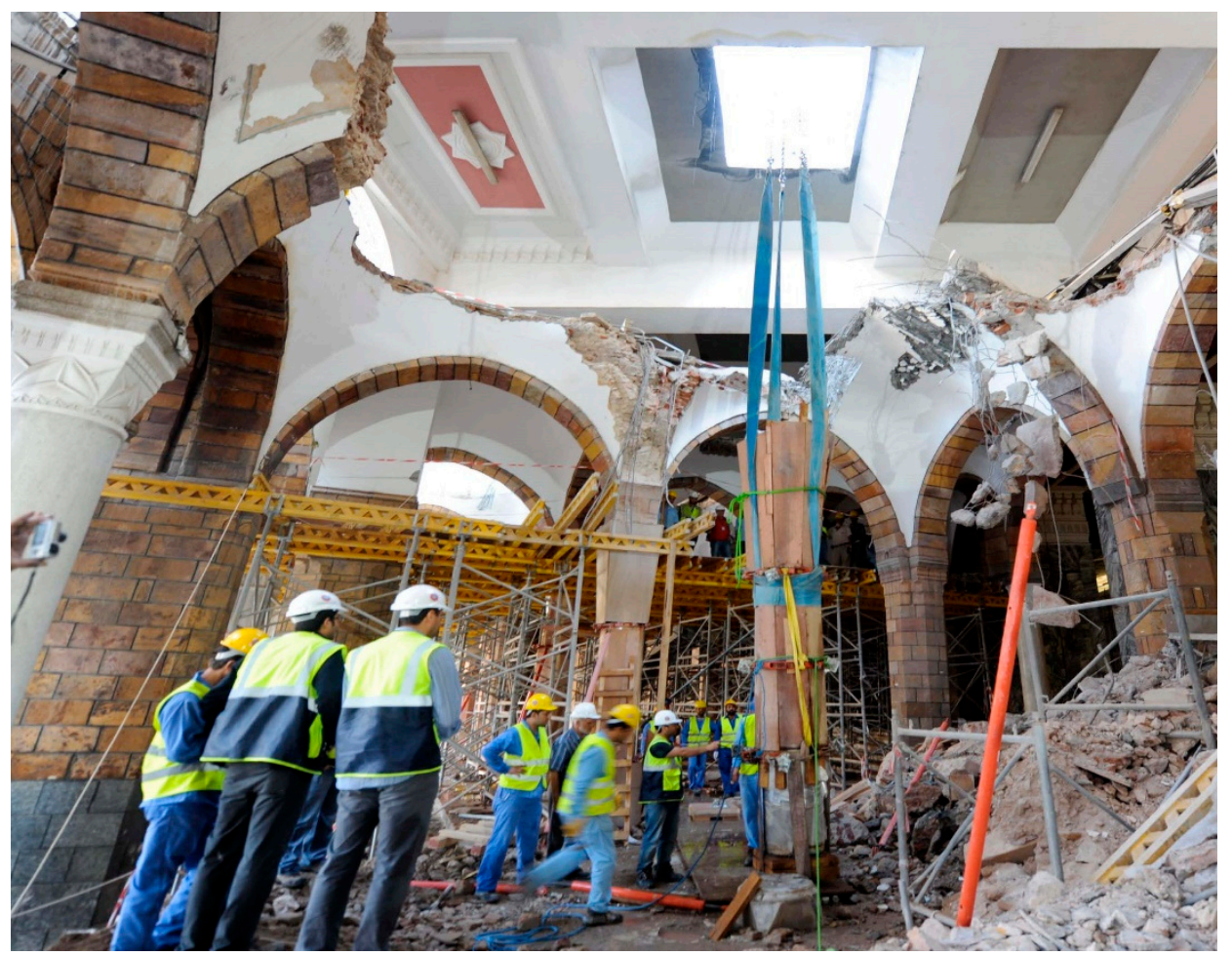

Figure 9. Dismantling and protection procedures for the archaeological columns for more sustainability.

\subsection{Construction Phase}

During the interviews, the experts mentioned nine factors causing a delay in the construction phase, such as the design constructability and modification factor. The project was designed to allow an additional number of floors to be added in the future without the need for demolition and the spaces between the columns were large to facilitate the movement of visitors. These things made the design difficult to implement and affected the time of the project in addition to the design modifications during the project execution works.

One more delay factor mentioned was the site conditions and constraints, which imposed a set of restrictions on the project management. This factor was a common factor between the demolition and construction phases. In fact, this factor affected the execution time negatively as there was difficulty in handling the required materials and in the movement of the equipment due to the narrow entrances, exits, and corridors connected to the construction site.

Another delay factor was mentioned during the interview sessions, which was providing a safe access for the visitors in order to move between the project areas safely. In fact, this factor was a common factor in both demolition and construction phases. It should be noted that the demolition works could be started in the safe access area only when providing an alternative safe access to the visitors. On the other hand, all the works had to be stopped in the safe access which existed in the construction area in order to serve the visitors until providing an alternative safe access. In fact, during the interview session with the experts, it has been highlighted that it was necessary to reserve a safe access area within the range of the demolition or construction area, hence, all the execution works in this safe access area had to be completely stopped to assure safety for the Mataf's visitors. As a result, reserving this area from the working space led to a considerable narrowing of the allowable space for the working process and then a delay in the working process in the demolition or construction project areas due to two reasons. The first was the inevitability of reserving a relatively large space for safe access, due to the relatively huge number of hourly visitors to the main Mataf complex and the necessity of assuring their safety while crossing within the project area. On the other hand, the second reason was logistical, in that the safe access divided the demolition or construction area of the project 
into two separate areas that hindered the smooth movement of the equipment, tools, and laborers within the demolition or the construction areas of the project as in Figure 6.

Furthermore, there was conflict between the execution of some parts of the project and the alternative temporary projects. In fact, some parts of the project were delayed because of their conflict with the temporary projects being executed to reduce the pressure on visitors. This was evident in the Temporary Mataf project, which was temporarily executed during the project period to reduce the pressure on visitors, which led to a delay in some parts of the project until the dismantling of the Temporary Mataf.

Moreover, the factor of the rate of completion was affected by the tests related to the archaeological elements dismantled during the demolition. A series of tests was carried out on the archaeological elements that were dismantled from the project during the demolition phase and the appropriate ones were subsequently sorted to be used in the construction phase. These tests and the repairing works that some elements needed required a period of time, which led to a delay in the start of these works at the project site.

On the other hand, one of the main reasons for the delay in the construction of archaeological parts was due to the difficulty in providing alternative materials similar to the archaeological elements and obtaining the approvals required from the consultants of the project before starting these works at the site. The specifications and quality of the alternative archaeological materials were of a very high standard in order to guarantee the sustainability of these materials. For example, Figure 10 shows sample panels, the first panel showing the alternative stones created to match the color and specifications of the archaeological stones in the second panel. Such careful procedures to protect the stone panels have been generalized for building materials for all archaeological parts in order to warrant the culture sustainability and virtuous appearance for all similar archaeological components.

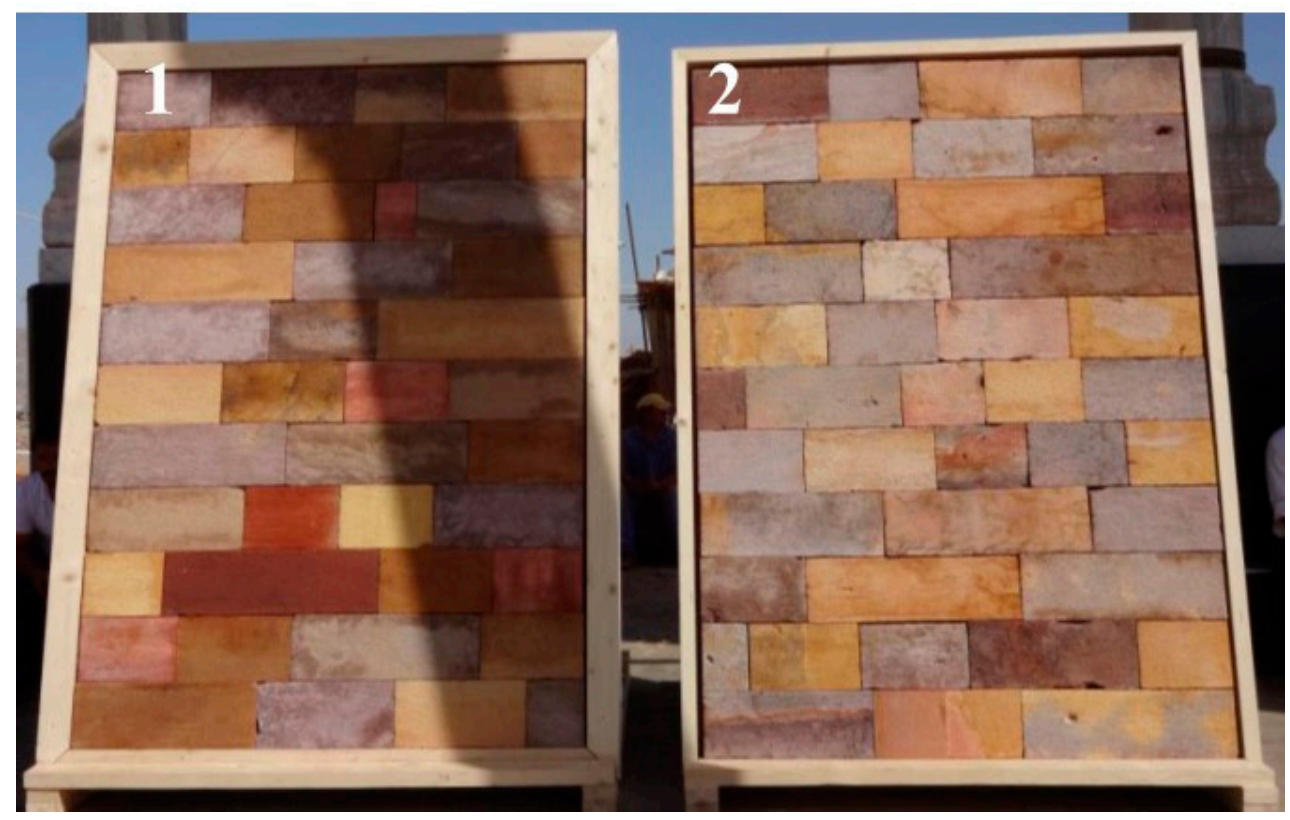

Figure 10. Stone sample panels for sustainability purpose; panel number 1 shows the alternative stones, while panel number 2 shows the archaeological stones.

Furthermore, in some areas of the project, there was an overlap in the works between the archaeological parts and nonarchaeological parts and this led to the delay in the archeological parts until the completion of the execution of nonarchaeological parts, which was due to the safety requirements and the difficulty in the execution of all these works together.

The labor productivity factor decreased due to the design difficulty and the hot weather conditions in addition to the interruption of works at the site during prayer times. 
In addition to the safety requirements, a number of conditions was imposed on the project, including leaving a buffer zone between the demolition and construction works. Construction works in the buffer zone area could not be started until the demolition was completely done. This has led to delays in the construction works in areas near the demolition areas.

\section{Discussion}

All the factors mentioned in all 14 interviews with the experts on the Al Mataf Expansion Project were recorded and considered in the study. The results of the interviews were similar to a great extent and there is a clear agreement among the engineers interviewed on the delay factors in the project. Based on the results of the opinions of the experts interviewed, the collected delay factors were divided into two parts, the first relating to the demolition phase and the second relating to the construction phase, as shown in Figure 11.

The results indicate that there are five factors for delays related to the demolition phase: rerouting work, providing alternative safe access, site conditions and constraints, dismantling archaeological elements, and back-propping works. Furthermore, there are nine delay factors related to the construction phase: the design constructability and modification, providing alternative safe access, site conditions and constraints, conflict between the execution of some parts of the project and the alternative temporary projects, speed of completion of the tests related to the archaeological elements dismantled during the demolition, providing alternative and similar materials for the archaeological elements, the overlap between the execution of archaeological parts and nonarchaeological parts, labor productivity, and delays in the construction work adjacent to the demolition work.

It is clear by reviewing the previous 14 factors that there are common factors between the phase of demolition and construction, which are providing alternative safe access and site conditions and constraints. The site conditions and constraints factor is similar to the previous studies related to the construction projects as shown in Table 1. Furthermore, the remaining four factors affecting the demolition phase characterize these types of reconstruction projects.

As for the nine delay factors affecting the construction phase, we note the presence of three factors which are shared with previous studies related to the construction projects and they are: design constructability and modification, labor productivity factor, and site conditions and constraints. As for the six remaining delay factors, they are unique to the reconstruction projects and they are different from the previous studies.

In spite of researchers initially thinking that there is a similarity between the delay factors reported in the current and the previous studies for the reconstruction projects, there is a major difference in whether the definition or the application, in this context, thoroughly reviewing and examining the delay factors in previous studies related to the reconstruction projects and considering carefully their detailed clarifications and definitions regarding all these factors, has been carried out. The result of this investigation shows that there is almost a complete difference between the delay factors that have been collected from the interviews with the experts working in the Mataf Expansion Project (the current study) and the ones reported in the previous studies (for example, with thoroughly studying the poor documentation factors mentioned in the previous studies and the rerouting works for all electrical and mechanical utilities, which is the first factor related to the demolition phase). In fact, the poor documentation factor is a result of the lack of good and clear documentation of the project, especially in terms of drawings, and sometimes the old documents of the project are missed. As a result of this issue, the experts may need to do additional tests in the project prior to the reconstruction work and thus it will be a factor in project delays. However, the rerouting factor for all electrical and mechanical utilities has resulted from two matters. The first one is the need to cut and transform the electrical and mechanical systems in the demolition area which were working as one unit integrated with each other within all phases of the project. The second matter is to secure the alternate routes to ensure the continuity of the work of these systems in the other phases of the reconstruction project. 


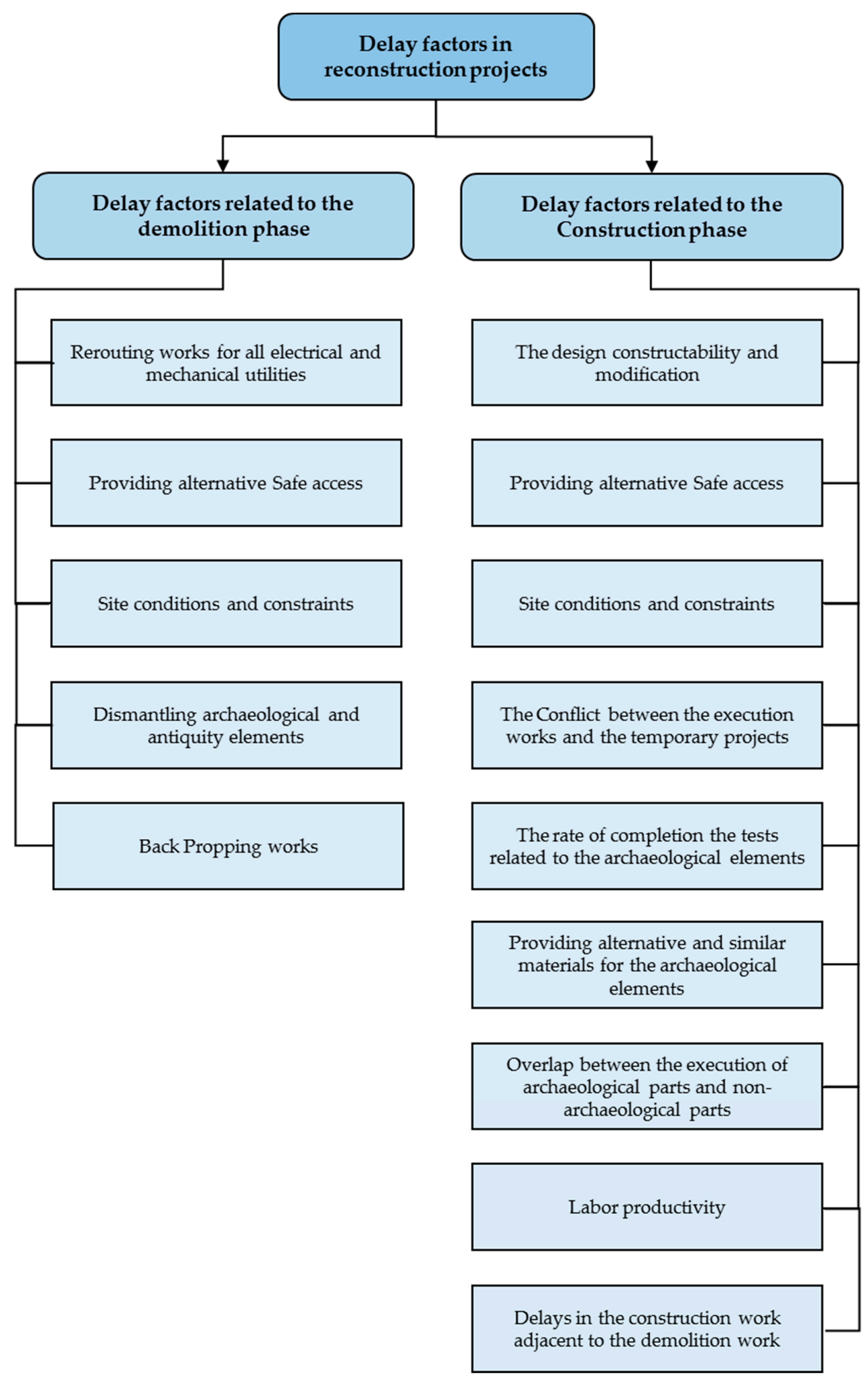

Figure 11. Delay factors in reconstruction projects.

\section{Conclusions}

There are many previous studies that defined and identified the delay factors in the various construction projects in order to avoid or reduce the multiple negative consequences that might result from such a delay and hence readjust the project implementation. On the other hand, avoiding the possibility of a delay occurring will ensure better ongoing and future sustainable operation during and 
after the project implementation. However, the studies are still limited in terms of the reconstruction projects of great importance, which remain under operation during the project execution period. A case study was conducted on the Mataf Expansion Project in Mecca in Saudi Arabia, which is one of the greatest projects in Mecca, Saudi Arabia.

The study shows a number of delay factors, which are divided into two groups:

Factors affecting the demolition and dismantling phase duration

- Rerouting works for all electrical and mechanical utilities in the area to be demolished

- Providing alternative safe access

- Site conditions and constraints

- Dismantling archaeological and antiquity elements

- Back-propping works

Factors affecting the construction phase duration

- The design constructability and modification

- Site conditions and constraints

- Providing alternative safe access

- The conflict between the execution works and the temporary projects

- The rate of completion of the tests (archaeological elements)

- Providing alternative and similar materials for the archaeological elements

- Overlap between the execution of archaeological parts and nonarchaeological parts

- Labor productivity

- Delays in the construction work adjacent to the demolition work

The comparison of the above factors with those of the previous studies related to the construction projects shows the differences between the delay factors. The main issues for the difference between the delay factors are the two types of works in the reconstruction projects, which are the demolition and construction works. Added to this are the inability to separate the entire project from the outside world and the continuity of the operation of the project during the demolition and construction works, especially the need for safe access for the visitors. In fact, the safe access factor was mentioned in all the 14 interview sessions as a major factor of the delay in the reconstruction project. The safe access area is a very important path for the visitors to move through the project complex, and due to this issue, special arrangements for all the demolition and construction works should be planned or might be stopped totally in this area for safety reasons. Moreover, the experts in the Mataf Expansion Project emphasized the negative effects of the safe access path on the reconstruction project duration. Finally, for those reconstruction projects that include archaeological and antiquity elements, there is a possibility to experience delay due to the necessity of giving special attention to the building materials of these elements during the dismantling process and seeking similar or alternative building materials. In order to assure culture sustainability of these archaeological and antiquity elements, it is recommended to take this into account during the project plan to avoid delay and merit a successful ongoing plan and future sustainable operation after project completion.

The study recommends the following for future research:

I. Conduct a number of studies on the reconstruction projects of great importance and cultural sustainability in order to define and identify all the delay factors that may affect the execution time.

II. Sort the delay factors in the reconstruction projects according to their impact on the project duration.

III. Develop a mathematical model by using the delay factors, which allows the calculation of the length of possible delay periods in reconstruction projects. 
Author Contributions: B.A.K. designed the research and conducted the analysis; Y.S.P. and A.E.-S. supervised the study; all authors equally wrote the manuscript. All authors read and approved the final manuscript.

Funding: The authors appreciate the technical and financial support received from research grant coded UMRG RP025A-18SUS funded by University of Malaya.

Acknowledgments: The authors would like to thank so much the data supplier. We also thank all reviewers and the Editor-In-Chief for their insightful comments that have improved the quality of the final manuscript.

Conflicts of Interest: The authors declare no conflicts of interest.

\section{References}

1. Opeyemi, M.K.; Samson, O.A.; Olabode, O.M.; Olanrewaju, D. An Assessment of the Causative Factors and Effects of Delays in Building Construction Projects in Osun State, Nigeria. J. Econ. Sustain. Dev. 2015, 6, 29-38.

2. Bal, M.; Bryde, D.; Fearon, D. Stakeholder Engagement: Achieving Sustainability in the Construction Sector. Sustainability 2013, 5, 695-710. [CrossRef]

3. Chan, A.P.C. Time-cost relationship of public sector projects in Malaysia. Int. J. Proj. Manag. 2001, 19, $223-229$. [CrossRef]

4. Assaf, S.A.; Al-Hejji, S. Causes of delay in large construction projects. Int. J. Proj. Manag. 2006, 24, 349-357. [CrossRef]

5. Ahmed, S.M.; Salman, A.; Kappagantula, P.; Gollapudi, D. Delays in Construction: A Brief study of the Florida construction industry. In Proceedings of the ASC 39th Annual Conference, Clemson, SC, USA, 10-12 April 2003.

6. Le'sniak, A.; Zima, K. Cost Calculation of Construction Projects Including Sustainability Factors Using the Case Based Reasoning (CBR) Method. Sustainability 2018, 10, 1608. [CrossRef]

7. Shebob, A.; Dawood, N.; Shah, R.K.; Xu, Q. Comparative study of delay factors in Libyan and the UK construction industry. Eng. Constr. Archit. Manag. 2012, 19, 688-712. [CrossRef]

8. Fugar, F.D.K.; Agyakwah-Baah, A.B. Delays in building construction projects in Ghana. Australas. J. Constr. Econ. Build. 2012, 10, 103-116.

9. Abdul-Rahman, H.; Takim, R.; Min, S.W. Financial-related causes contributing to project delays. J. Retail Leis. Prop. 2009, 8, 225-238. [CrossRef]

10. Al-Emad, N.; Rahman, I.; Nagapan, S.; Gamil, Y. Ranking of Delay Factors for Makkah's Construction Industry. MATEC Web Conf. 2017, 103, 03001. [CrossRef]

11. Jarkas, A.M.; Haupt, T.C. Major construction risk factors considered by general contractors in Qatar. J. Eng. Des. Tech. 2015, 13, 165-194. [CrossRef]

12. Mydin, M.; Sani, N.; Salim, N.; Alias, N. Assessment of Influential Causes of Construction Project Delay in Malaysian Private Housing from Developer's Viewpoint. E3S Web Conf. 2014, 3, 01027. [CrossRef]

13. Memon, H.; Rahman, A.; Akram, M.; Ali, N.M. Significant factors causing time overrun in construction projects of Peninsular Malaysia. Mod. Appl. Sci. 2014, 8, 16-28. [CrossRef]

14. Gardezi, S.S.; Manarvi, I.A.; Gardezi, S.J. Time Extension Factors in Construction Industry of Pakistan. Procedia Eng. 2014, 77, 196-204. [CrossRef]

15. Mahamid, I. Micro and macro level of dispute causes in residential building projects: Studies of Saudi Arabia. J. King Saud Univ. Eng. Sci. 2014, 1, 12-20. [CrossRef]

16. Sweis, G. Factors Affecting Time Overruns in Public Construction Projects: The Case of Jordan. Int. J. Bus. Manag. 2013, 23, 120-129. [CrossRef]

17. Mahamid, I. Contributors to schedule delays in public construction projects in Saudi Arabia: Owners' perspective. J. Constr. Proj. Manag. Innov. 2013, 3, 608-619.

18. Gündüz, M.; Nielsen, Y.; Özdemir, M. Quantification of Delay Factors Using the Relative Importance Index Method for Construction Projects in Turkey. J. Manag. Eng. 2013, 29, 133-139. [CrossRef]

19. Aziz, R.F. Ranking of delay factors in construction projects after Egyptian revolution. Alex. Eng. J. 2013, 52, 387-406. [CrossRef]

20. Alinaitwe, H.; Apolot, R.; Tindiwensi, D. An Investigation into the Causes of Delay and Cost Overrun in Uganda's Public Sector Construction Projects. J. Constr. Dev. Ctries. 2013, 18, 33. 
21. Mahamid, I. Common risks affecting time overrun in road construction projects in Palestine: Contractors' perspective. Constr. Econ. Build. 2013, 13, 45-53. [CrossRef]

22. Kazaz, A.; Ulubeyli, S.; Tuncbilekli, N. Causes of Delays in Construction Projects in Turkey. J. Civ. Eng. Manag. 2012, 18, 426-435. [CrossRef]

23. Doloi, H.; Sawhney, A.; Iyer, K.; Rentala, S. Analysing factors affecting delays in Indian construction projects. Int. J. Proj. Manag. 2012, 30, 479-489. [CrossRef]

24. Fallahnejad, M. Delay causes in Iran gas pipeline projects. Int. J. Proj. Manag. 2012, 31, 136-146. [CrossRef]

25. Gidado, K.; Niazai, G. Causes of project delay in the construction industry in Afghanistan. In EPPM2012; University of Brighton: Hastings, UK, 2012.

26. Al Jurf, N.A.; Beheiry, S. Factors affecting cost and schedule in Qatar's residential compounds projects. Int. J. Eng. Manag. Econ. 2012, 3, 117-134. [CrossRef]

27. Ameh, O.; Osegbo, E. Study of relationship between time overrun and productivity on construction sites. Int. J. Constr. Supply Chain Manag. 2011, 1, 56-67. [CrossRef]

28. Khoshgoftar, M.; Abu Bakar, A.; Osman, O. Causes of delays in Iranian construction projects. Int. J. Proj. Manag. 2010, 10, 53-69. [CrossRef]

29. Enshassi, A.; Mohamed, S.; Abushaban, S. Factors affecting the performance of construction projects in the Gaza strip. J. Civ. Eng. Manag. 2009, 15, 269-280. [CrossRef]

30. Al-Kharashi, A.; Skitmore, M. Causes of delays in Saudi Arabian public sector construction projects. Constr. Manag. Econ. 2009, 27, 3-23. [CrossRef]

31. Abd El-Razek, M.; Bassioni, H.; Mobarak, A. Causes of Delay in Building Construction Projects in Egypt. J. Constr. Eng. Manag. 2008, 134, 831-841. [CrossRef]

32. Le-Hoai, L.; Lee, Y.; Lee, J. Delay and Cost Overruns in Vietnam Large Construction Projects: A Comparison with Other Selected Countries. KSCE J. Civ. Eng. 2008, 12, 367-377. [CrossRef]

33. Sweis, G.; Sweis, R.; Abu Hammad, A.; Shboul, A. Delays in construction projects: The case of Jordan. Int. J. Proj. Manag. 2008, 26, 665-674. [CrossRef]

34. Toor, S.-U.-R.; Ogunlana, S. Problems causing delays in major construction projects in Thailand. Constr. Manag. Econ. 2008, 26, 395-408. [CrossRef]

35. Sambasivan, M.; Soon, Y. Causes and effects of delays in Malaysian construction industry. Int. J. Proj. Manag. 2007, 25, 517-526. [CrossRef]

36. Alaghbari, W.; Razali, M.; Kadir, S.; Ernawat, G. The significant factors causing delay of building construction projects in Malaysia. Eng. Constr. Arch. Manag. 2007, 14, 192-206. [CrossRef]

37. Faridi, A.; Sayegh, S. Significant factors causing delay in the UAE construction industry. Constr. Manag. Econ. 2006, 24, 1167-1176. [CrossRef]

38. Abdul-Rahman, H.; Berawi, M.A.; Berawi, A.R.; Mohamed, O.; Othman, M.; Yahya, I.A. Delay mitigation in the Malaysian construction industry. J. Constr. Eng. Manag. 2006, 132, 125-133. [CrossRef]

39. Aibinu, A.A.; Odeyinka, A. Construction delays and their causative factors in Nigeria. J. Constr. Eng. Manag. ASCE 2006, 132, 667-677. [CrossRef]

40. Lo, T.Y.; Fung, I.W.H.; Tung, K.C.F. Construction delays in Hong Kong civil engineering projects. J. Constr. Eng. Manag. ASCE 2006, 132, 636-649. [CrossRef]

41. Acharya, N.K.; Lee, Y.D.; Im, H.M. Investigating delay factors in construction industry: A Korean perspective. Korean J. Constr. Eng. Manag. 2006, 10, 177-190.

42. Frimpong, Y.; Oluwoye, J.; Crawford, L. Causes of delay and cost overruns in construction of groundwater projects in a developing countries; Ghana as a case study. Int. J. Proj. Manag. 2003, 21, 321-326. [CrossRef]

43. Al-Khalil, M.; Al-Ghafly, M. Delay in public utility projects in Saudi Arabia. Int. J. Proj. Manag. 1999, 17, 101-106. [CrossRef]

44. Mezher, T.; Tawil, W. Causes of delays in the construction industry in Lebanon. Eng. Constr. Arch. Manag. J. 1998, 5, 252-260. [CrossRef]

45. Chan, D.; Kumaraswamy, M. A comparative study of causes of time overruns in Hong Kong construction projects. Int. J. Proj. Manag. 1997, 15, 55-63. [CrossRef]

46. Kaming, P.; Olomolaiye, P.; Holt, G.; Harris, F. Factors influencing construction time and cost overruns on high-rise projects in Indonesia. Constr. Manag. Econ. 1997, 15, 83-94. [CrossRef]

47. Ogunlana, S.O.; Promkuntong, K.; Jearkjirm, V. Construction delays in a fast-growing economy: Comparing Thailand with other economics. Int. J. Proj. Manag. 1996, 14, 37-45. [CrossRef] 
48. Assaf, S.A.; Al-Khalil, M.; Al-Hazmi, M. Causes of delay in large building construction projects. ASCE J. Manag. Eng. 1995, 11, 45-50. [CrossRef]

49. Mansfield, N.R.; Ugwu, O.O.; Doran, T. Causes of delay and cost overruns in Nigerian construction projects. Int. J. Proj. Manag. 1994, 12, 254-260. [CrossRef]

50. Arditi, D.; Gutierrez, A.E. Factors affecting U.S. contractors' performance overseas. J. Constr. Eng. Manag. 1991, 117, 27-46. [CrossRef]

51. Dlakwa, M.M.; Culpin, M.F. Reasons for overrun in public sector construction projects in Nigeria. Int. J. Proj. Manag. 1990, 8, 237-241. [CrossRef]

52. Arditi, D.; Akan, G.T.; Gurdamar, S. Reasons for delays in public projects in Turkey. Constr. Manag. Econ. 1985, 3, 171-181. [CrossRef]

53. Krizek, R.; Lo, W.; Hadavi, A. Lessons learned from multiphase reconstruction project. J. Constr. Proj. Manag. Innov. 1996, 122, 44-54. [CrossRef]

54. Pavlovskisa, M.; Migilinskasa, D.; Antuchevičienèa, J.; Urbab, I.; Zigmundb, V. Problems in reconstruction projects, BIM uses and decision-making: Lithuanian case studies. Procedia Eng. 2017, 208, 125-128. [CrossRef]

55. Guest, G.; Bunce, A.; Johnsons, L. How many interviews are enough? An experiment with data saturation and variability. Field Methods 2006, 18, 59-82. [CrossRef]

(c) 2018 by the authors. Licensee MDPI, Basel, Switzerland. This article is an open access article distributed under the terms and conditions of the Creative Commons Attribution (CC BY) license (http:/ / creativecommons.org/licenses/by/4.0/). 